\title{
AN ENCOUNTER AND ITS IMPACT: THE VISIT OF JOHN R. MOTT IN CLUJ-NAPOCA/KOLOZSVÁR AND HIS IMPRESSION UPON LÁSZLÓ RAVASZ
}

\author{
ÁRPÁD KULCSÁR*
}

Debrecen Reformed Theological University

\begin{abstract}
In this paper I examine one of the effects of László Ravasz's (1882-1975) theological thinking, former professor of Practical Theology at Protestant Theological Institute, KolzosvárCluj-Napoca, namely the development of his spiritual life and its impact on his theological scientific position. Due to the limitations of the scope of this paper, I could present the less wellknown views of Ravasz's work on the mission. John R. Mott's lecture in Kolozsvár-Cluj-Napoca provides, among others, the certainty that in the modern theoretical approach of the young Ravasz he approached the tasks of pastoral ministry, preaching, dissemination of the gospel, theological education in a modern and actual way. This notion was not perfect, but it helped to bring about a new impetus for the Hungarian Protestant worldview that was stuck in rationalism and liberalism, and for the value theology to constitute a positive transition to the dialectical theology. Ravasz was an authentic representative of this transition.
\end{abstract}

KEYWORDS: mission, value theology, spiritual life, J. R. Mott, László Ravasz.

\section{Introduction}

If we want to map the effects upon László Ravasz's thinking, we should look at each of the thousands of phases of a huge life work. No one has ever done so, although there are significant, valuable partial results. The work of Lóránt Hegedüs Senior entitled Neo-Kantian and Virtue Theology in Hungary (Hegedüs 1998) unequivocally dominates as a basic reference in the issue, being unavoidable in this respect. There is no theological scientific work in the past thirty years not making a reference to this work. This study created during the period 1966-67 proved to be a duly authentic source, as it also turns out from the preface of the volume that László Ravasz (certified by a letter dated January 30, 1970) read the manuscript and even made some comments. [A few examples: Tóth Z (1855-1938) Adalékok a magyar református teológia fejlödéstörténetéhez, DRHE, Szegedre kihelyezett Vallástanári Tanszék.

* ÁRPÁD KULCSÁR, Reformed minister, Ph.D. student at Debrecen Reformed Theological University, Hungary. He is an Assistant Professor at Partium Christian University, Oradea-Nagyvárad, Romania. Email: kulcsarpad@partium.ro. 
Ethelbert Stauffer Teológiai Kutatóintézet. Szeged, 2004; Tóth-Matolcsi László (2005) Mühely a lehetetlenséghez. Kapcsolódási pontok Bibó István és Ravasz László életmüvében. Argumentum kiadó, Bibó István Szellemi Műhely. Ifj. FEKETE Fekete K (2008) Tudománnyal és a hit pajzsával. Válogatott Makkaitanulmányok. Kolozsvár: Az Erdélyi Református Egyházkerület kiadása]

Detailed discussion of these effects would outweigh the scope of this paper. I proposed an issue of less interest at first hearing as the aim of my research. Among the complex features of the character and scientific profile of a Christian personality, such as László Ravasz, it is not negligible that he himself was a 'man of faith' or he cultivated the theological sciences only on a rational basis; showing only the professional peak of his preaching age or called 'from faith to faith'.

The aim of this paper is to examine the impact of John R. Mott on László Ravasz and to draw conclusions on the significance of this effect from theological point of view. In order to point out the significance of Mott's visit, in the first part of my paper I briefly describe the missionary situation of the 1819th century Hungarian Reformed Church; in the second part I write about John R. Mott and the circumstances of his visit, and finally I wish to point out the value of Mott and Ravasz's encounter.

\section{An Outline of the Missionary Situation of the Hungarian Reformed Church in the 18th-19th Centuries}

Looking at the mission history of the Hungarian Reformed Church, it is easily to be noted that, in addition to certain fragments, chapters of the general church history handbooks, lexicons and university courses, there are still very few accessible publications offering us relevant information. Anne-Marie Kool's epoch-making work is still fundamentally important from the point of view of the issue (Kool 1995), and the research works carried out by Ábrahám Kovács and László Gonda valuably contribute to a more complete picture. In the following few lines, I summarize the historical situation in which the missionary life of the Hungarian Reformed Church evolved. [Kovács Á (2004) A Budapesti Ev. Ref. Németajkú Leányegyház eredete és története 1858-1869. The History of the German-speaking reformed affiliated church of Budapest 1858-1869 (bilingual edition). Debrecen: A D. Dr. Harsányi András Alapítvány kiadványai. Kovács Á (2001) The origin of Scottish-Hungarian church relations: the settlement and the first years of the Scottish mission in the 1840s (with a Hungarian preface and summary). Debrecen: A D. Dr. Harsányi András Alapítvány Kiadványai 4. Gonda L (2008) The service of evangelism, the evangelism of service. The impact of John R. Mott, Hendrik Kraemer, Johannes C. Hoekendijk, Willem A Visser't Hooft on the development of the understanding of mission in the Reformed Church of Hungary, 1910-1968. Zoetermeer: Boekencentrum]

This is the time to find a way when the Reformed Christian mission receives the impulses primarily from Western Europe, especially from the 
tendencies for the renewal of the Church. Settled theoretical vision does not exist, it becomes mature only in the 20th century, but this century is also characterized by the lack of a unified vision. The initiation of various missionary work can be linked each to an enthusiastic and self-sacrificing person who, by dedicating his or her life, wishes to proclaim the Gospel of Christ to the dormant Hungarian souls and other non-Christians within and outside of Hungary.

After the Turkish occupation ended, the rule of the Habsburg dynasty took place in Hungary. The emergence of the counter-reformation and the effectiveness of its operation, as well as the Pro-Catholic attitude of the Habsburg rulers, among others, led to the fact that by the end of the 18th century not even $20 \%$ of the whole population of the country was protestant. In intellectual and psychic terms, the gradual effacement of puritanism and pietism can be observed for the benefit of rationalism and liberalism.

Since the Habsburg state censorship allowed the publication of the Heidelberg Catechism only if questions and answers offending the Roman Catholics are omitted, and thanks to the aforementioned spiritual changes, a few theological works of a scientific nature were created, especially the sermon volumes lived their heyday.

These circumstances show that the Reformed Church lived its period of self-restraint, the reformer's spiritual heritage was dimmed, and its place was replaced by less rigorous theological rationalism.

Since the Reformed Church was almost 100\% Hungarian, as opposed to the Roman Catholic Church, where the Croatians, the Germans and the Slovaks were present beside the Hungarians; and the Lutheran Church (the German-Saxons and the Slovaks), made the Habsburg Emperor House fear the most, the principle of 'one religion, one constitution, one language' being endangered especially by the Reformed Church. Surely it is no coincidence that the leaders of the Revolution and War of Independence of 1848-49 were Protestant aristocrats and noblemen. After the fall of the War of Independence, several Reformed pastors and teachers were sentenced to death or imprisoned. These measures led to a general lack of pastors and had the most unfavorable effect on the Reformed missionary work. Various attempts, primarily based on the intellectual and material support of a foreign missionary society, testify the presence of the desire for mission, but no breakthrough results could be produced. The effect of the Scottish Mission concentrated mainly on Budapest, and the missionary activity of the German Reformed Church in Pest, were also the few exceptions that could effectively work the mission's thinking in the Reformed circles from the second half of the nineteenth century.

At that time, the 'science' of the mission was unknown in theological education. It was only in 1910 when the Universal Convention of the Reformed 
Church of Hungary decided to include the theory of mission in the subjects to be taught in seminary and to make it compulsory for all students.

At the beginning of the 20th century, the Hungarian Reformed Church sought to establish an independent theological clarification of the mission concept. By the end of the 19th century and the beginning of the 20th century, the official ecclesiastical leadership did not consider as its task to conduct internal and foreign missions. The Hungarian missionaries, without exception, were delegated by a foreign missionary association, they were primarily laymen's, not pastors. In the territory of Hungary of that period, these foreign companies carried out various missionary and diaconical services being known as revival movements.

More and more people recognized the importance of being able to formulate to the Hungarian reformed community and clarify what the mission is, and it must be explained that it is the Church's most important task. There were more attempts in these times, all of which made a significant contribution to clarify the Church's view on this issue.

However, the process of recovery was refrained by several factors. One of them was historical one due to the unforeseen breakage in the life of the Hungarian Reformed Church after World War I, which was hard to recover. The Austro-Hungarian Monarchy ceased to exist, the Empire was torn apart, and therefore the Hungarian Reformed Church was also torn apart, part of its membership was to be found in other countries from one day to the other. Another factor was that, due to the world war, the Church faced a serious economic climate, as well, which did not serve the mission. A third factor was that, due to fragmentation, Hungarian Christianity became introverted, the foreign mission was less and less interesting, and in disjointed parts, such as Transylvania, the Transylvanian Reformed Church faced the challenge that the Eastern Christianity, the Orthodoxy, remote and foreign up to that time, got very close all at once. Therefore, this introversion forced the Church rather to defend itself, and this had a significant influence on the definition of the mission concept. The missionary command '... go and make disciples of all nations' (Matthew 28:18-20) remained alive, but 'Feed my lambs [...] Take care of my sheep' (John 21:15-16) and 'Go rather to the lost sheep of the Israel' (Matthew 10:5-6) came into view.

Many have attempted to define mission both in Hungary and Transylvania. These definitions sometimes led to internal tensions and debates, the essence of which was not personality but the sincere effort to revive the mission. From this era, we mention Gyula Forgács (1879-1941), László Ravasz (18821975), Jenő Sebestyén (1884-1950), Sándor Virágh (1908-1964), Sándor Makkai (1890-1951), János Victor (1888-1954), Jakos Lajos (1894-1989). This list, without being exhaustive, includes a number of Hungarian and 
Transylvanian theologians, pastors, and members of the Church who in this time also had significant activities in defining the mission.

\section{John R. Mott's Personality and His Visits in Hungary}

John R. Mott (1865-1955) American Methodist first visited Hungary in 1895, then in 1903 again. There are very few details about these occasions, but Kool, referring to certain 'traditions', states that visits may have been outlined first at the London World Congress in 1894 of the Young Men's Christian Association (YMCA) when Mott met Aladár Szabó, one of the young leaders of the Hungarian Reformed Church (Kool 1995:161). Mott was member of the leadership of the Student Volunteer Movement (SVM), but he also played an important role in the YMCA and the World Student Christian Federation (WSCF). Mott saw serious fields of mission in Hungary, supporting the already existing Christian Youth Association (Szabó 1895: 3).

Mott was a Methodist, but this did not constitute an obstacle to having enough openness in the Reformed circles. Methodism, which developed within the Anglican Church in the second half of the 18th century, was not characterized by tempting members from other denominations, it was not primarily about recruiting members. John and Charles Wesley, the first leaders of Methodism as an internal revival movement, were heavily influenced by the Herrnhuttian community of Count Nicolaus Ludwig Zinzendorf, however, being different from them in some important issues. This was e.g. the typically Calvinist doctrine, the predestination, being completely rejected by the Methodists, and claimed that the man's salvation depends entirely on his free will. Human actions were also more important than recognized in Reformed circles.

Mott's spiritual roots originate from evangelicalism, which, by the end of the 19 th century and early 20th century, was divided into two trends: fundamentalism and the so-called social gospel. Mott was the representative of the latter. His work, The Evangelization of the World in this Generation was published in 1900, which was soon followed by a second edition. The book is inspired by missionary optimism, which in these years typically characterized Western, primarily American missionary circles. The title of the book also became a kind of motto, not by chance, since it reflects the position of millenarian perceptions that triggered serious disputes in the 19th century, according to which the emphasis is on 'here and now', that is, the kingdom of God will not prevail in the future, but it is a present ethical reality. According to the representatives of the social gospel, it is very important to eliminate ignorance in the world as ignorance is the cause of sin that gets into the way of human development. This notion, however, was not completely different from the rationalism that had long been dominating in Europe and the idea of enlightenment was not unknown to him. 
Gospel and culture were believed to be interwoven in a form that, of course, had been best executed in the United States of America, so one of the mission's goals was to offer the world's poorer peoples the blessings of the American civilization and the American lifestyle (Bosch 1991: 260). David Bosch points out that the social gospel was influenced by European theological ideas, including the ideas of Albert Ritschl, or Ernst Troeltsch, referred to by Lóránt Hegedűs among the names having influence on Ravasz's work (Bosch 1991: 295).

Mott belonged to the new type of Western missionaries who did not come from the working class, but started to work from renowned universities, that is to say they were educated people, well-trained in a particular field who felt at home in social life. János Victor met him at the SVM's Liverpool Conference in 1908. This was also a preparation for a subsequent visit. In 1909, John R. Mott spent three weeks in Hungary when he not only traveled to Budapest but also to Sopron, Sárospatak, Debrecen and Cluj-Napoca. This visit is much more documented. We can find out more about the Church's press of the age (Forgács 1909: 264-265). János Victor accompanied John Mott on his circuit as an interpreter. During the time spent together, Mott had a serious spiritual impact on the young theologian, who later translated Mott's work into Hungarian, with the title The Decisive Moment of the Christian Missions.

The enthusiasm generated by Mott in Budapest was repeated everywhere he paid a visit. Perhaps it is no exaggeration to claim that his visit was of a mission-historical significance for the Transylvanian Reformed Church. It had barely been a decade since the transfer of the Theological Faculty from Aiud to Cluj-Napoca, and at the same time, the rationalism and liberalism, the national sentiment and the pietist background were accepted together in the faculty. In Mott, the radicalism of the gospel came to Transylvania, bringing the new Christian missionary program that had been announced worldwide. In the more traditionalist Reformed medium in Transylvania and ClujNapoca, far away from the central circulation of the Monarchy, where Calvin was discovered again in those times, the call for inner spiritual renewal and personal faith was addressed in a novel tone.

The Reformed Survey, a weekly journal established a year before, reported the followings about the event: 'Our faculty of theology was the center of the youth life in Cluj on the second day of this month. John Mott's university lectures gathered the college youth in such a great number that our ceremonial hall was fully crowded. From 11-12 in the morning, the theologian held lectures for theology students between 5-7 pm, and for university students from 8 to $10 \mathrm{pm}$, the lectures being also attended by people interested in the moral life of youth (Bishop Kenessey, György Boros, Karoly Nagy, György János, Kecskeméti, Ravasz, József Sándor, etc.). His speech will be presented 
in the following editions of our journal based on sufficiently reliable tachygraph records. Not only to present the trend of his aspirations to those interested, but especially to reveal its practical trend and the secret of the great influence of his speeches: the use of psychology, the importance of personal experience. We will have the opportunity to return to these. Until then, we invite all noble souls who feels responsible for the fate of our youth, the future leaders of our nation to plant the work of John Mott in the domestic soil. God bless the man of apostolic zeal and his work.'

The unknown author also lists in his report the name of László Ravasz among the participants mentioned by name. The permanent editor of the Reformed Survey, a young (27 years old) successor to Professor Albert Molnár at the Practical Theological Department, wrote an editorial about Jon Mott (Ravasz 1909: 249-252) in the same issue of the journal, under the pseudonym 'Aleph'. It is clear that László Ravasz was behind the pseudonym of 'Aleph' due to the fact that more than a decade later, we find literally the writing in question (Ravasz 1924: 87-91) published in the volume On the halfway of the journey of human life (2nd edition), and republished of the next year due to the great interest manifested by the audience. Based on the title of the writing, we can think that it is about John R. Mott, but this is far more than that, perhaps it explains that it was included in a later volume of the writing as the actuality of the formulas did not lose their value.

Let us first see the thoughts that had a profound effect on Mott's audience, including László Ravasz. The speech published in sequels in the Reformed Survey, recorded based on János Victor's translation by shorthand-a wellconstructed, easy-to-follow, evangelistic teaching - begins with Mott's experience acquired during his travels around the world, with illustrative examples in support of the fact that humanity is suffering from spiritual atrophy, its reason being that man does not use his moral and spiritual abilities. The gradual deterioration leads to the loss of these abilities (Mott 1909: 270). Among other consequences, it mentions uncertainty resulting from the neglect of spiritual life. Sin gradually enters human life, so someone who once condemned something, will later indulge it in the lives of others, then in his or her own, as well, and then he or she will feel it even desirable until it will be finally considered indispensable for the future (Mott 1909: 271-272). If someone does not use the abilities received from the Creator, he or she is at risk of his salvation. If this behavior does not mean abuse, but without using it, we will become like the servant in the parable whom Jesus Christ called 'Evil Servant', as in Matthew 25:14-30 and Luke 19:11-27 (Mott 1909: 288).

Mott called on his audience asking practical questions that would make it easy for anyone to examine if he did not suffer from spiritual atrophy? He rejects the position that sooner or later a sudden, turbulent conversion will occur changing everything in a split of a second, but also that according to 
which the person who experiences the symptoms of spiritual paralysis, he or she is finally lost as there is no cure for this kind of illness.

'There is hope!'- he encouraged his students, and said, 'From experience I have been living for decades among young people, but I did not find a young man I would say that he was completely lost. [...] Let us thank God for being young men. Observe the following word of the soul: Before the age of 30 we are in the age of habit and character formation, and especially before the age of 25. Between 25 and 30 it is harder to adopt good habits. It is not impossible, but it is harder than climbing the mountain. Very hard. I say: use these shapeable years' (Mott 1909: 290).

It is quite possible that Mott's speech using the recent achievements of the contemporary psychology was best addressed at this point to his audience, including László Ravasz, who was then 27 years old. Mott also stated that it was necessary for all pastors to study the psychology in order to perform their service more efficiently.

In the final part of the speech, two terms are emphasized: 'practice' and 'life'. At this point, László Ravasz felt himself certainly to be the most invocated. If we look at his lecturer's speech of 15th September 1907, we can discover more similar thoughts. In his inaugural, 'life' is the key expression as the title of the speech also shows: The truth of life. Since such a speech can be perceived also as a lecturer program, we can observe here the expanding and strengthening of Ravasz's practical theological program: 'In fact, there is a task of the practical theology: to personalize Christianity, which will soon become only a historical memory or a graceful tradition; to change what has been called so far as lifetime...' (Ravasz 1907: 13)

He also published a small study in 1907, written for the new series of the Reformed Preacher Repertory (Ravasz 1907: 1). He formulates thoughts similar to those in his inaugural speech. When criticizing the standards of preaching, he determines the major concern with the contemporary preaching: 'From the preaching's is missing exactly what gives its meaning: personal life' (Ravasz 1907: 6). Later, as if we were to find Mott's thoughts, just formulated a little differently: 'And if we looked at the nature of life, we find that it is primarily developing. Wasting life is impossible; either grows, or falls, and if it does not grow, then it inevitably falls apart; this kind of life is not life, but its destruction' (Ravasz 1907: 8). A new world view is needed, but it is not only to the pastors who preaches, but for the whole congregations. And what is this view of the world like? 'This worldview will be more realistic than the old ones, instead of supernatural, it will rest on natural sciences and its accent will be placed on the eternal benefits of this life' (Ravasz 1907: 15). As if the range of thoughts of the social gospel were glittering in these lines, Ravasz's conception rhymes with the views represented by Mott. 
How strong was upon Ravasz the effect that a well-known and powerful speaker of the age, who called on tens of thousands of the young throughout the world with the gospel about Christ, formulated the same ideas as initially he himself? 'What does it mean to be a Christian? It means knowing Christ and becoming more like him, through knowledge and experience. Does it take time? It requires work for a lifetime' (Mott 1909: 290). This is how Mott ended his lecture. A year later, he was elected President of the World Mission Conference in Edinburgh. His career was followed by the editorial staff of the Reformed Survey, and from time to time the readers reported on a variety of events. In 1916 it could be read that Mott also protested against the American ammunition production; in 1947, it was remembered that when he was 82 , he received the Nobel Peace Prize with Balch Green Emily [Református Szemle (1947) 42(1): 12]; in 1965, on the centenary of his birth, he was paid tribute to with a few rows. [Református Szemle (1965) 60(3): 216.]

\section{The Effect of the Encounter between John R. Mott and Ravasz László}

'I have not heard any people whom I was so interested in as in him'- so confessed Ravasz the decisive nature of the encounter. In his autobiographical writing My Memorials, which appeared decades later than he was written, in 1992, we find out that this encounter was an important stage in his conversion. His mother grew up in a pastoral family, and the 19th-century clerical atmosphere did not please the daily life of the faith, and although his father was a lively church-worshiper, he did not leave any trace in the formation of Ravasz's faith. The religious lessons of the school, the preparation for confirmation, also did not affect the young Ravasz more deeply, approaching faith more intellectually even as theologist. It was on the four hundredth anniversary of Calvin's birth, when he first deepened in the Reformer lessons, but also met John R. Mott.

He faced hardship in his family life, and 'as it was not dramatic, the release of an inner tension with a complete collapse and stormy recovery, but a raising awareness and a slow blossoming like Aaron's rod (Numbers 17:8): my conversion was neither instantaneous, I cannot fix a day or hour, but a gradual inner enlightenment, warmth, reaching the top, the conscious orientation of my life to Christ, to His cross, a more complete surrender, the ever deeper enrooting in it. This is what nourished and shaped my theological thinking, teaching, preaching, and pastoral service' (Ravasz 1992: 112). It seems as if Mott's position on conversion had been fully realized in Ravasz's personal spiritual life!

Mott's lectures confirmed that Christianity must be practiced and manifested in all aspects of life, both in personal life, as in pastoral ministry, but also in the teaching department. His recognition is programmatic according to which at the faculty of theology, beside the pure theoretical lecture, 
practical training is at least as important, under which he does not mean the practical acquisition of the profession of clerical work but also the formation of the inner world of the students, namely based on the Christian pattern. This statement leads to an important question: 'How to do this if we do not know the spirit and the laws of Christian life?' (Ravasz 1924: 90) The young lecturer of practical theology understood at that time that in order to be able to work effectively as a pastor in the church, he must know not only the Bible, but also the human souls he shepherds. The old conception was that there was no difference between audience and audience in the pastoral care: 'We are preaching to everyone, teaching or shepherding everyone alike.' This must be changed! Although the short writing about Mott does not reveal how to imagine it more precisely, recognition of this is a huge step forward not only in his personal life and career, but also in the whole pastoral and church work.

It is also necessary to refer about his views on the mission. As a first step, he considered the clarification of concepts to be his job, looking for the correct word usage. In his study 'Church and Association', he thinks that all church work: preaching, teaching, and pastoral care should also be seen as a mission. It separates three categories based on the mission between: (1) the congregation, (2) the masses turned away from Christ or heathens, or (3) the unbelievers. Live congregation are needed, he said, therefore members must be guided to the firm decree of Christ and support them in the testimony. This will enable the Church to carry out real missions in the long run (Ravasz 1938: 439-458).

In his reports as a Bishop, he urged the formulation of a new mission statement by the Reformed Church, which finally came true in 1931. As long as the church-law was born, he was constantly working to move the barriers between the various missionary societies, associations and the official church to fully promote their approach. Until 1921, at the Annual Meetings of the Reformed Church District in Dunamellék, the mission was not even an issue, twenty years later, at these meetings, there were long reports of missionary achievements.

In 1928, at the Budapest Reformed Theological Academy, he expressed his views on the Reformed Foreign Mission. Like many others, he also started from verses Matthew 28, 18-20. He also believed that this word gave the authority to the Church. Mission of the Church is God's task. It is also important Acts 4, 20 'For we cannot help speaking about what we have seen and heard' and 1 Timothy 2:4 '[God]... wants all men to be saved and to come to a knowledge of the truth.' Based on these two quotes, this is how its mission statement can be summarized: 'God wants the mission, Jesus commands, and the believer is forced with the irresistible launch of the Holy Spirit' (Ravasz 1928: 111121). Therefore, the call of God is for everyone, but the person through whom he will realize it depends on his sovereignty. 
One of the novelties in his mission statement was that he sought to provide its dogmatic basis. In his opinion:

- The great prerequisite of the mission is the fact of sin, the destruction of the human nation, the fading of the righteous knowledge of God.

- Every person has the image of God. Pagans also have some value. At this point, the German theological concept is discussed: it cannot be said of paganism what German theologians state that, there was no statement beyond the knowledge of Christ, it would be the scene of absolute failures and satanic superstitions. Of course, Ravasz reveals an essential difference between Paganism and Christianity, but accepts the perception of logos spermatikos. Accordingly, paganism has a divine statement, distorted and corrupted, and it has its values, there is also some clarity, guidance.

- The absoluteness of the statement in Christ is the fact that Christ is the ultimate, complete, immutable truth (Ravasz 1928: 111-121).

His mission statement seems to be soteriological, that is, the purpose of the mission is to rescue the soul who has fallen in sin. David Bosch pointed out that the 19th-century revival movements were also characterized by this missionary impulse (Bosch 1991: 28). From a Christological point of view, however, he concludes that one of the foundations of truth is Christ, but as a teacher and not as the only savior of the world.

The universality of humanity plays an important role in its mission-mindedness. The human genus coheres in any of its fragmentation. In his view, if there were no Christian mission, politicians would be forced to figure something out instead of it so that mutual serving of each other and the principle of mutual responsibility can prevail. That is, Christian mission is a cultural unifying force. Foreign affairs are, in this sense, also foreign policy, one of the greatest pedagogical work of mankind (Ravasz 1928: 111-121). Ravasz's range of vision is wide, his missionary approach is characterized by humanistic, cultural, political, economic and pedagogical factors. He regarded the missionary as the bearer of Christ and the bearer of the Holy Spirit. This must be transmitted through the above-mentioned factors. If that is missing, then we cannot talk about mission. It is not the task of the mission to force European culture into the Asian or African peoples, but to put all of these into Christianity. Christian truth must transcend these foreign cultures by pervading individuals.

Missionary work consists of preaching, holy teaching, and above all, the dissemination of the Bible. The mission is primarily to be realized by the Church's consecrated ministers, but he still speaks about doctors, teachers, or highly educated people (Ravasz 1928: 111-121). When László Ravasz came 
to Budapest as a pastor of the Calvin Square Congregation in 1921, he came to a secularized world where there was no trace of Transylvanian spirit or similar attachment to the church. At the same time, he faced the problem he had met in Transylvania: the mission was not carried out by the official church, but foreign missionary organizations. After his election to Bishop, he considered as his task to officially facilitate the mission to be carried out by churchman, to which he sought to formulate a program and to elaborate details. His point of view was not struggling, but integration. He wanted to facilitate the better functioning of the mission and make it more effective, so he considered everyone as partner in this program. One of its key ideas was cooperation, which avoids competition in mission turning away any obstacles in the way of effectiveness. Another important element of his program was 'to make the mission a church and to make the Church a mission'.

László Ravasz was one of the leaders of the Hungarian Reformed Church who again pointed to the importance of the relationship between Church and Mission. 'Every church will be healed by initiating foreign mission. In the life of every church, bathing in the waters of Bethesda is a foreign mission (Ravasz 1928: 111121).' The missionary impulse differs from the perception of his contemporaries that his mission conception is expanded by the addition of the cultural element. As long as Gyula Forgács sees the ultimate goal of the mission in the dissemination of the Kingdom of God, this means for Ravasz creating this culture. At this point, there is a deviation also from the Dutch missionary approach. In case of Gyula Forgács, the effect of Gisbertus Voetius is evident (Bosch 1991: 256-257), where the concept of mission includes everything that can promote the cause of reformation. But it is different from Jenő Sebestyén's approach, who primarily formulates his mission under the influence of Abraham Kuyper. The purpose of the mission is church planting. (This thought can be discovered also in Voetius' work: plantatio ecclesiae aut ecclesiarum) (Sebestyén 1932: 12). However, his approach is identical with the Dutch trend and its Hungarian representatives according to which missionaries should be consecrated pastors who can baptize and administer holy communion.

Since dialectics theology had a relatively late effect on László Ravasz, the idea of 'mission Dei' taken from Karl Barth is only indirectly transmitted. His contemporary, Sándor Virágh, speaks already clearly about the fact that the subject of the mission is God himself. The mission is His will, He will perform it (Virágh 1934: 7). Karl Barth defined the mission as the act of God. Its essence is to propagate God's grace to the chosen. Its purpose is to invite people to know God consciously and thus to realize the true purpose of their lives. Christopher C. J. Wright starts also from a similar thought, in his work The mission of God, 'missio Dei', which giving exactly the biblical and dogmatic 
substantiation of the mission that is still missing in Ravasz's perception (Wright 2006).

Although Ravasz dealt more specifically with the Reformed doctrine of predestination, it did not play a particular role in his missionary view. It is to observe clearly the ambition to lay the foundations of the missionary biblical and dogmatic grounds, however, despite good intentions, the firm foundation shows weaknesses. It is evident also in the very broad interpretation of this mission, but also in the fact that he found the basis in the actual practical situation of the church. There is also a lack of a more thorough dealing with mission consciousness. However, it is to be appreciated that mission is considered important also within the Church, as there were some who did not want to hear about internal mission. This, in their view, would have meant that there was an inner paganism in the church which, they-in their viewconsidered to be completely excluded. Ravasz already recognized at that time that Hungarian Christianity and culture were in general at risk, and the postChristian world of the late decades perfectly confirmed it, unfortunately.

He regards mission as very important, but he only relies on official ecclesiastical leadership in sending missionaries, and the churches do not have a say in it. It is also a point that differs from the contemporary Dutch conception of the time in which foreign mission is given place in the lives of churches (Jakos 1942: 200). At the same time, it was missing that the mission serves God's glory!

All in all, Ravasz was one of those who experienced the life of the Hungarian Reformed Church after the First World War, who sought to put the mission in the right place in the service of the Church and, as Bishop, tried to strengthen in many ways its significance. The historic era was not favorable either for him to deepen in clarifying the mission-related principles, but this was not possible either for his contemporaries. However, he decisively contributed to the fact that the mission could become more and more part of the Hungarian Reformed Church's public consciousness.

\section{Bibliography}

Bosch DJ (2005) Paradigmaváltások a misszió teológiájában. Budapest: HarmatPMTI, Originally published as Transforming mission. Paradigm Shifts in Theology of Mission. New York: Orbis Books.

Fekete K (2008) Tudománnyal és a hit pajzsával. Válogatott Makkai-tanulmányok.

Kolozsvár: Az Erdélyi Református Egyházkerület kiadása.

Forgács Gy (1917) A misszió elmélete. Practica theológiai tanulmány. Pápa.

Forgács Gy (1925) A belmisszió és cura pastoralis kézikönyve. Pápa: Református Egyházi Könyvtár 14. 
Forgács Gy (1909) Mott János és a diákok evangelizációja. Protestáns Szemle $21(*): 4-265$.

Gonda L (2008) The service of evangelism, the evangelism of service. The impact of John R. Mott, Hendrik Kraemer, Johannes C. Hoekendijk, Willem A Visser't Hooft on the development of the understanding of mission in the Reformed Church of Hungary, 1910-1968. Zoetermeer: Boekencentrum.

Hegedűs L (1996) Újkantiánus és értékteológia. Budapest: Mundus kiadó.

Jakos L (1942) A holland szigorú református egyház gyülekezeti élete és missziói munkája.

Kool A M (1993) Az Úr csodásan müködik. A magyar protestáns külmissziói mozgalom (1756-1951). Budapest: Harmat_Protestáns Missziói Tanulmányi Intézet. I kötet (1995); II. kötet (1997); III. kötet (2000). Originally published as: God moves in a Mysterious Way, The Hungarian Protestant Foreign Mission Movement (1756-1951). Zoetermeer: Boekcentrum.

Kovács Á (2004) A Budapesti Ev. Ref. Németajkú Leányegyház eredete és története 1858-1869. The History of the German-speaking reformed affiliated church of Budapest 1858-1869. (bilingual edition). Debrecen: A D. Dr. Harsányi András Alapítvány kiadványai 10.

Kovács Á (2001) The origin of Scottish-Hungarian Church Relations: The Settlement and the First Years of the Scottish Mission in the 1840s (with Hungarian preface and summary). Debrecen: A D. Dr. Harsányi András Alapítvány Kiadványai 4.

Literáty Z (2009) Homiletika és retorika. Múltbeli kapcsolatuk és jelenkori lehetöségeik. Homiletikatörténeti áttekintés. Budapest: Doktori értekezés.

Makkai S (1936) Az egyház missziói munkája. In Protestáns Szemle 45(*): n.p.

Mott János előadása. Református Szemle II. évfolyam, 1909. május 14.17 szám.

Mott János előadása. Református Szemle II. évfolyam, 1909. május 21. 18 szám.

Ravasz L (1938) Egyház és egyesület. In Legyen Világosság. Budapest: Franklin társulat. I, pp. 439-458.

Ravasz L (1928) Külmisszió. In A Tháborhegy ormán. Szerzői kiadás, Kolozsvár, pp. 111-121.

Ravasz L (1942) Belmisszió. In Korbán. Budapest: Franklin társulat, II. pp. 524-526.

Ravasz L (1942) A külmisszió. In Korbán. Budapest: Franklin társulat, II. pp. 529-530.

Ravasz L (1942) Ismét a belmisszió. In Korbán. Budapest: Franklin társulat, II. pp. 532-534.

Ravasz L (1924) Mott János. In Az emberélet útjának felén. Kolozsvár: Az Út kiadása, pp. 87-91.

Ravasz L (1907-1908) Az élet igazsága. Székfoglaló beszéd. Kolozsvár: Értesítő.

Ravasz L (1907) Az igehirdetés megújhodása. In Református Prédikátori Tár. I. kötet. Ifj. Péter Károly (ed) Székelyudvarhely. 
Ravasz L (1992) Emlékezéseim. Budapest: A Református Egyház Zsinati irodájának Sajtóosztálya.

Sebestyén J (1932) A külmisszió református elvei és azok alkalmazása a gyakorlati egyházi életben. In Külmissziói évkönyv. Budapest, pp. 9-15.

Studens (1909): Mott R. János. Élet és Munka 1(1): n.p.

Studens (1909) Mott János és a magyar diákok. Élet és Munka 1(2): n.p.

Szabó A (1895) Budapesttől Londonig, emlékezés a KIE 13. Világkongresszusára. Budapest.

Tóth Z (2004) Adalékok a magyar református teológia fejlödéstörténetéhez (18551938). DRHE, Szegedre kihelyezett Vallástanári Tanszék. Szeged: Ethelbert Stauffer Teológiai Kutatóintézet.

Tóth-Matolcsi L (2005) Mühely a lehetetlenséghez. Kapcsolódási pontok Bibó Istuán és Ravasz László életmüvében. Argumentum kiadó, Bibó István Szellemi Mühely.

Virágh S (1934) A misszió dogmatikai alapvetése. In Jubileumi évkönyv. Budapest.

Virágh S (1936) A misszió fogalmi meghatározása. In Abesszinia és egyéb missziói tanulmányok. Budapest.

Virágh S (1938) A misszió fogalmi meghatározása. In Külmissziói kézikönyv. Budapest, 1938.

Wright CCJ (2006) The Mission of God. Unlocking the Bible's Grand Narrative. Grand Rapids, MI: InterVarsity Press. 